\title{
Entrepreneurial orientation in Mexican family businesses
}

\author{
José Luis Esparza-Aguilar a*, Argentina Soto-Macielb, Ma. Isabel De la Garza-Ramos ${ }^{\mathrm{c}}$ \\ a Universidad de Quintana Roo. Mexico. \\ b Universidad Anahuac, Argentina. Email: argentina.soto@anahuac.mx \\ c Universidad Autónoma de Tamaulipas. Mexico.Email: igarza@uat.edu.mx \\ *Corresponding author's email address: jlesparza@uqroo.edu.mx
}

\section{A R T I C LE IN F O}

Received: 27-10-2016

Accepted: 08-12-2016

Available online: 05-01-2017

\section{Keywords:}

Family business;

Entrepreneurial orientation;

Innovation;

Risk taking.

\begin{abstract}
A B S T R A C T
We examine factors affecting entrepreneurial orientation in Mexican family businesses. We aim to shed light on the relevance and value of such factors by analyzing five widely recognized dimensions: proactivity, innovation, risk taking, aggressiveness and autonomy. Results from a sample of 542 family businesses extracted from the INEGIENAFIN 2010 database and the first entrepreneurial stage of the Global Entrepreneurship Monitor (GEM) show a marked conservative tendency in the family businesses' entrepreneurial orientation.
\end{abstract}

JEL Classification : E32 ; L21; L25.

(C) 2016 The Authors. This is an open access article under the terms of the Creative Commons Attribution License 4.0, which allows use, distribution and reproduction in any medium, provided the original work is properly cited.

\subsection{Introduction}

The literature on family-owned enterprises has traditionally been concerned with deepening our understanding of the succession stage (Bird et al., 2002; Benavides et al., 2011; Yu et al., 2012). This has been confirmed by Benavides et al. (2011), who analyzed 684 research papers and identified that succession is the most widely studied topic, with 123 of them. This situation can mainly be explained by the recognition that the succession stage is one of the most critical issues in the continuity of the family business. Nonetheless, the study of succession has focused on the characteristics of its process, the influence of succession plans, some of the transitions tool, the relevance of management training and development or the impact of compensation schemes (Yu et al., 2012). However, little attention has been given to issues related to viables options to perennate the family business. Examples of such options include corporate entrepreneurship (Schöllhammer, 1982; Burgelman, 1984; Kanter, 1982; Guth and Ginsberg, 1990; Zahra, 1991), or the influence of the family dynamics on these businesses' entrepreneurship process (Aldrich and Cliff, 2003).

Benavides et al. (2011) found that as little as $4 \%$ of the analyzed research addressed the topic of entrepreneurship and innovation, and their focus was strategic management. The literature on entrepreneurship and innovation is predominantly descriptive. Therefore, they suggest the need for more empirical research on this topic and identify two new research perspectives: continuity and the capacity to take advantage of new opportunities.

The paper is made up of four major sections. First, the research literature on family businesses and entrepreneurial orientation is reviewed. Then the research methodology used is described. After that, the 
research findings are presented and discussed. Finally, the paper concludes with a discussion of the theoretical and practical contributions of the study, as well as its limitations and implications for future research.

\subsection{Literature review}

\subsection{Family businesses}

The notion of family business does not have an agreed-upon definition (Wortman, 1994: Cabrera and García, 1998; Poza, 2005; Sharma, 2012). However, there are three recurrent conditions when trying to understand this construct. First, the participation of family members in $i$ ) ownership of the business (Barnes and Hershon, 1976; Rosenblatt et al., 1985); ii) management (Beckhard and Dyer, 1983; Handler, 1989); and iii) the intention to become the successor (Miller and Rice, 1967; Churchill and Hatten, 1987). When looking back to its origins, it can be observed that for some authors the notion is necessarily dichotomous. Therefore, some definitions include both the ownership and management as part of the members' participation in the business (Bork, 1986; Davis, 1983; Gallo and Sveen, 1991); for some other authors, the notion entails ownership and continuity (Donelly, 1964). However, for some others, the definition of it is trichotomous; that is to say, the members necessarily participate in its ownership, management and continuity (Handler, 1989; Aragonés, 1992). In fact, all these positions are still polarized and no consensus has been reached at the international level to be able to compare and contrast them. The literature on family businesses has gradually made evident their differentiated behavior as a result of the interconnection and respective logics of the subsystems that make them up.

\subsection{Entrepreneurial orientation}

The corporate entrepreneurship is the result of two perspectives. On the one hand, there is an interest in reducing the risk capital. On the other hand, there is a need to generate a strategic alternative (Morris et al., 2010). In the first case, entrepreneurship gives origin to a new enterprise by choosing to enter a new market. In the latter, entrepreneurship seeks to create a competitive advantage (Kuratko, 2010) through the exploration of opportunities (Ireland et al., 2003) and is closely related to the organizational performance (Arzubiaga et al., 2012). The entrepreneurial behavior can become critical for family businesses (Astrachan, 2003), particularly for their capability of innovation and flexibility (Naman y Slevin, 1993), which constitute two differential characteristics of their entrepreneurial trait.

From this perspective, the entrepreneurial orientation (EO) notion emerges and different models aimed at facilitating their measurement have been proposed. Miller (1983), one of the pioneers, proposes three subdimensions: innovation, risk taking and proactivity and endorses their positive covariation. In this sense, the EO is the exent to which the top management is willing to take risks related to the business (risk taking dimension) in order to bring about change and innovation with the aim of gaining a competitive advantage for it (innovation dimension), and to be able to aggressively compete with others firms (proactivity dimension) (Arzubiaga et al., 2012). While various authors have been associated with this perspective (Covin and Slevin, 1989), some others have incorporated two more dimensions into the model, competitive aggressiveness and autonomy (Lumpkin and Dess, 1996). In this context, the EO is referred to as the processes, the decision-making practices and activities leading to a new entrance (to the market). The construct evolution presents two alternatives. While the first one makes reference to the capitalization of a series of interconnected internal processes, the second one appears to be focused on the opening of new market entry points.

Recently, Martin and Lumpkin (2003) introduce the notion of family orientation which is in sharp contrast with the entrepreneurial orientation conception that is more closely associated with an organizational level. In this sense, Cruz and Nordqvist (2007) and Kellermanns and Eddelston (2006) in agreement with Martin and Lumpkin (2003) suggest that the EO increases during the founder period and lowers as new generations are integrated into the business. For their part, Zellweger et al. (2012) propose the family entrepreneurial orientation (FEO) notion to refer to family's attitudes and mentalities to engage in entrepreneurial activities.

Arzubiaga et al., (2012) have significantly contributed to the understanding of the family business entrepreneurial orientation notion trough identifying some dimensions based on the literature review. Among the results obtained, they acknowledge that two main interests are privileged in the related literature. The first emphasizes the relationship between EO and the business performance and constitutes the most widely studied perspective (Rauch et al., 2001) recently incorporating external factors into the models (Kellermanns and Eddleston, 2006; Wang, 2008; Moreno and Casillas, 2008). The second identifies factors that influence the business' EO (Covin and Slevin, 1991; Borch, Huse and Senneseth, 1999; Baum, Locke and Smith, 2001; Wiklud and Shepherd, 2005). However, other studies have sought to understand the influence of certain organizational variables on it (Wiklud, 
1999; Zahra and Garvin, 2000; Lumpkin and Dess, 2001; Wiklud and Shepherd, 2005). It seems to suggest that there is a general agreement that the businesses' $\mathrm{EO}$ is a multidimensional construct.

\section{$2.3 \quad$ Research model}

This study seeks to identify some of the Mexican family businesses' main behavioral characteristics during their entrepreneurial stage. It focuses on the proactivity, innovation, risk taking, competitive aggressiveness and autonomy dimensions. For the entrepreneurial activity classification, we have considered the Global Entrepreneurship Monitor (GEM, 2014) document, which states that the emerging enterprise is that whose existence in the market ranges from 3 to 42 months and generates the payment of wages and salaries. Such an enterprise has also gone through the initial stage of its development.

Hughes and Morgan's (2007) study uses five dimensions as independent variables. One of such variables is proactivity, which is related to the constant search for new markets and the introduction of new products or services that can help them gain a competitive advantage. The family business genesis and the superposition of its sub-systems strongly influence its performance and strategic approach due to the fact that a defensive strategy usually prevails in this type of enterprises (Arzubiaga et al., 2012), and, are, therefore, less proactive.

\section{H1: $\quad$ The Mexican family firms tend to be less proactive during their entrepreneurial stage in terms of expansion or growth.}

For Lumpkin and Dess (1996), innovation is considered as the willingness that an enterprise has to engage in and support new ideas, novelty, experimentation and the creative processes that give rise to new products, services or processes. Innovations can be either internal or external to the business. Internal innovation is inherent in the enterprise's organizational culture and is related to its capability to generate added value. External innovation gradually transforms products, services or processes. In this perspective, Schumpeter (1934) endorsed its importance by making reference to the "new combinations" that promoted the economy's dynamic evolution. In spite of the difficulty to avoid tautological traps between process and product innovation, the role played by innovation as an important component in EO has been recognized. The value of innovation has entailed, for example, the financial measurement devoted to I\&D (Miller, 1987); the enterprise's predisposition to acquire, develop or display technology (Zahra and Covin, 1993); or its capability to adapt itself to new processes (Miller, 1983). In the case of family businesses, Zellweger and Sieger (2010) claim that these processes favor the tendency to maintain a medium or lower level of external innovation and a medium or higher level of internal innovation. Nonetheless, there is the recognition that family firms are able to activate both internal and external innovation. In this article, external innovation is assessed, particularly, that related to the processes.

\section{H2: $\quad$ The Mexican family businesses tend to be more innovative with respect to ICT use during their entrepreneurial stage.}

H3: $\quad$ The Mexican family businesses tend to be less innovative with respect to their use of financial products as payment methods during their entrepreneurial stage.

About risk taking, it is related to the actions as a result of decision making in a context of a high level of uncertainty. For Lumpkin and Dess (1996), risk taking represents the management's level of willingness to compromise organizational resources when the decision has a considerable probability of failure. The literature review recognize that family businesses suffer from strategic inertia and risk taking aversion (Meyer and Zucker, 1989). Sometimes, these behaviors are associated with property concentration (Chandler, 1990); government structure (Fama and Jensen, 1983); or the grounds that the family's wealth assumes completely the eventual financial losses (Naldi et al., 2007). As result of such aversion, some strategic decisions such as the international expansion, the launching of a new product or the allocation of resources to I\&D are postponed (Schulze, Lubatkin and Dino, 2002). For the purposes of this study, risk taking is focused on the financial dimension and is understood as the business propensity for debt, which implies greater responsibilities with important stakeholders such as banks and suppliers.

H4: $\quad$ The Mexican family businesses tend to take fewer risks when obtaining credit from financial institutions during their entrepreneurial stage.

H5: $\quad$ The Mexican family businesses tend to take more risks when obtaining credit from suppliers during their entrepreneurial stage.

Competitive aggressiveness is understood as the business' tendency to directly and intensively challenge its competitors with the aim of surpassing its rivals within the sector (Lumpkin and Dess, 1996). The objective is to 
gain a greater level of participation in the market (Hughes and Morgan, 2007). In relation to the family business behavior, there are contrasting opinions regarding the organizational stage, the role of image and the generational level it is in. However, the tendency is for businesses to engage in defensive, rather than offensive, competitive aggressiveness (Arzubiaga et al., 2012). The interaction between the business and the family plays an important role in the development of an appropriate internationalization process, which is managed with a lower level of intensity; and therefore, it starts later than that in other businesses (Gallo et al., 2008). In this study, competitive aggressiveness is seen as the family business' participation in international markets.

\section{H6: $\quad$ The Mexican family businesses tend to be less aggressive to compete in and explore new markets abroad.}

Autonomy can be considered as an independent action undertaken by an individual or a team to start up an idea or a vision and to realize it (Lumpkin and Dess, 1996). Scholars such as Mintzberg (1973) and Mintzberg and Waters (1985) have argued that this trait is closely related to a strong leadership. Shrivastava and Grant (1985), for their part, state that this is an autocratic exercise, which is common in small businesses where the action of an individualized vision prevails (Mintzberg and Waters, 1985). Zellweger and Sieger (2010) claim that a greater degree of autonomy exists in family businesses due to their conservative approach (Zellweger and Sieger, 2010). Other perspectives suggest that autonomy is dependent on business size, leadership style or ownership characteristics. Nordqvist et al. (2008) state that internal autonomy is inherent in the management practices within the organization (for example, in relation to shareholders) and external autonomy is related to different agents such as banks, suppliers, customers or financial markets. For Burgelman (1984), autonomy reinforces innovation, promotes the beginning of business projects and enhances competitiveness and internal effectiveness (Arzubiaga et al., 2012). This study focuses on the kind of autonomy related to business management and control.

H7: $\quad$ The Mexican family businesses tend to exert greater levels of autonomy for business management and $c$ ontrol during the entrepreneurial stage.

\subsection{Method}

This study analyzes data from the "Encuesta Nacional de Competitividad, Fuentes de Financiamiento y Uso de Servicios Financieros de las Empresas" (ENAFIN, 2010), conducted by the "Banco Interamericano de Desarrollo" (BID), the "Comisión Nacional Bancaria y de Valores" (CNBV), and the "Instituto Nacional de Estadística y Geografía" (INEGI). The survey was conducted during the last trimester of 2010, using a sample of 986 enterprises, which represents a sampling frame of 281,545 due to the expansion factor included. For the purposes of this study, the total data about each type of business is first presented; after that, the family business sample used is provided.

Table 1: Total sample and sampling frame composition

\begin{tabular}{lrrrr}
\hline Stratum & & Sample & \multicolumn{2}{c}{ Sampling Frame } \\
\cline { 2 - 5 } & Number & $\%$ & Number & $\%$ \\
\hline Micro & 367 & 37 & 137,585 & 49 \\
Small & 328 & 33 & 114,262 & 41 \\
Medium & 148 & 15 & 23,545 & 8 \\
Large & 143 & 15 & 6,152 & 2 \\
Total & 986 & 100 & 281,545 & 100 \\
\hline
\end{tabular}

Source: own design based on ENAFIN (2010).

According to the ENAFIN (2010) report, the data from the 986 businesses enable us to make inferences regarding business size for a considerable number of variables at the national level (the numerical variables estimates presented a wide variance, though). The sampling method employed was stratified and multi-staged. The stratification considered previous results obtained from Economic Censuses and the business categories developed by the Mexican Ministry of Economy according to the number of employees. The sample included businesses belonging to the construction, commercial and the private non-financial services sectors (including transportation) with more than 5 employees (Table 2). The study had national coverage taking into consideration localities with a population of 50,000 or more inhabitants.

Table 2: Employee number ranges by economic sector

\begin{tabular}{lrrr}
\hline Stratum & Commercial & Service & Industry \\
\hline Micro & 6 a 10 & 6 a 10 & 6 a 10 \\
Small & 11 a 30 & 11 a 50 & 11 a 50 \\
Medium & 31 a 100 & 51 a 100 & 51 a 250 \\
Large & 101 y más & 101 y más & 251 y más \\
\hline
\end{tabular}

Source: Official Gazette of the Mexican Federation dated June 30, 2009, with the exception of the micro stratum. 
Based on data presented above and for the purposes of this study, the following Table shows the sample of 542 family businesses used and the sampling frame $(157,136)$, which was segmented from the entire database in order to be able to conduct the respective analysis.

Table 3: Sample and sampling frame composition of family businesses

\begin{tabular}{lrrrr}
\hline Stratum & & Sample & \multicolumn{2}{c}{ Sampling Frame } \\
\cline { 2 - 5 } & Number & $\%$ & Number & $\%$ \\
\hline Micro & 244 & 45 & 89,247 & 57 \\
Small & 172 & 32 & 56,520 & 36 \\
Medium & 74 & 14 & 9,123 & 6 \\
Large & 52 & 9 & 2,246 & 1 \\
Total & 542 & 100 & 157,136 & 100 \\
\hline
\end{tabular}

Source: Author's design based on ENAFIN (2010).

\subsection{Variables}

For the purposes of this study and based on the literature review, the following variables have been established. They include the dependent, independent and control variables that are part of the research model used.

\subsubsection{Dependent variable}

\section{Entrepreneurship:}

This variable has been obtained based on the last two stages of the entrepreneurial activity process established by the Global Entrepreneurship Monitor (GEM, 2014): (a) owner or manager of a new business (Emerging enterprises). It refers to the entrepreneur whose activity generates the payment of wages and salaries and has overcome the initial stage. This type of entrepreneurs already has been exercising their entrepreneurial practice between 3 and 42 months; (b) owner or manager of an established business (Well-established enterprises). It refers to the entrepreneur whose businesses have been in existence for more than 3.5 years (42 months).

To achieve this, a dummy variable was constructed. Such variable has a value of 1 when the business finds itself in the entrepreneurial stage, with up to 3.5 years in the market, and a value of 0 when the business is already established, with more than 3.5 years of existence.

\subsubsection{Independent variables}

Among the independent variables that have been established taking into consideration factors related to the family businesses' entrepreneurial activity are:

\section{Proactivity:}

Proactivity has been considered as part of the expansion or widening of new establishments or businesses that entail the incorporation of new or greater variety of products or services that the enterprise has to offer in the market in order to gain competitive advantage. To do so, a categorical variable has been constructed. Such variable has a value of 1 if the business owns more than one establishment or branch, and 0 otherwise.

\section{Innovation in ICT:}

External innovation performed in product, process or service, is a key factor in corporate entrepreneurship. Therefore, a variable has been established. This variable has a value of 1 if the business has incorporated information and communication technology as an important element in the productive or service process, and 0 otherwise.

\section{Innovation in financial products:}

As part of innovation that the business has incorporated into its management processes is the use of different financial products as payment methods. This includes the way the business pays its customers, suppliers and employees. To do so, a dummy variable has been constructed. Such variable has a value of 1 if the business has used electronic payment options such as electronic and bank transfers, and 0 otherwise.

\section{Risk taking:}

As part of the business' risk taking approach towards different financial and non-financial resources, it is important to assess its relation to entrepreneurship. To achieve that, a variable has been established. This variable has a value of 1 if the business has acquired debt using resources from suppliers or short term credit lines from financial institutions, and 0 otherwise. 
Competitive aggressiveness:

As part of a competitive strategy, the business entrepreneurial activity has been incorporated. In doing so, a dummy variable has been created. It has a value of 1 if the business has sold products or services in foreign markets, and 0 otherwise.

\section{Internal autonomy:}

This variable has been measured through the control the business's main owner has within it. The variable has a value of 1 if the business manager is also its main owner or partner, and 0 otherwise.

\section{External autonomy:}

This variable has been measured through the control on the part of another business or economic group. The variable has a value of 1 if the business or economic group is the owner of $50 \%$ or more of the company.

\subsubsection{Control variables}

\section{Gender:}

Gender has become an important factor in the business world nowadays, with more women engaged in business managerial roles every day. Therefore, this variables has been measured through a dichotomic question, which has a value of 1 if the manager or main owner is male, and 0 if female.

Size:

The business size has been measured through the number of both temporal and permanent employees the business has hired during the study period. The businesses were grouped into micro, small, medium or large categories.

\section{Sector:}

The economic activity sector to which the business belongs has been considered too. The businesses were categorized into the two sectors where they mostly participate. It has a value of 1 the business belongs to the tertiary sector (commerce, services, transportation), and 0 if they belong to the secondary one (construction, manufacturing industry).

\subsection{Results}

The main results obtained from the data analysis are presented in this section. The results, which are shown in the following crossed tables, are presented using the Chi square test given that measurable data are used in category scales.

Table 4 shows that family enterprises are more conservative, rather than proactive, during their entrepreneurial stage regarding business expansion to aggressively compete with other businesses within their markets (Arzubiaga et al., 2012). This situation is common in this type of enterprises due to their cautious approach to promoting the business' permanence in the market. These findings are consistent with those of Zellweger and Sieger (2010); and therefore, hypothesis H1 may be accepted.

Table 4: Entrepreneurship and proactivity

\begin{tabular}{lrrr}
\hline Business expansion & Entrepreneurship & $\begin{array}{r}\text { Well-established } \\
\text { businesses }\end{array}$ & Sig. \\
\hline One single establishment or branch & $91.3 \%$ & $75.0 \%$ & $* * *$ \\
More than one establishment or branch & $8.7 \%$ & $25.0 \%$ & \\
\hline
\end{tabular}

Note: Pearson's $\chi 2$ test and Yates correction for continuity; $\left(^{*}\right): \mathrm{p}<0.1 ;\left({ }^{* *}\right): \mathrm{p}<0.05 ;\left({ }^{* *}\right): \mathrm{p}<0.01$;

(NS) Statistically non-significant.

Source: author's design.

The next Table shows that the majority of family businesses are more likely to implement and use Information and Communication Technologies during their entrepreneurial stage. Such innovation is part of the resilience process that these businesses must adopt to be able to face the changes in the context in which they operate. Innovation in family businesses has been studied by Craig and Moores (2006), who have found a relationship between innovation and the family business' life cycle as this type of enterprises showed significantly greater levels of innovation during the initial stages of their development. As a result of that, and the Zellweger's and Sieger's (2010) findings, hypothesis H2 may be accepted.

Based on the aforementioned, it is important to point out that the family business has specific characteristics due to the influence that the family or family group has on the business and their relationship with the other members. 
This sometimes hinders innovation due to the obstacles or inertias that exist within the family. In the following Table, it can be observed that innovation in financial products as payment methods is not incorporated by entrepreneurial family businesses as part of their processes. This is mainly due to their fear of change due to the lack of ideas for new proposals (Webb, Ketchen and Ireland, 2010) which in turn leads to lower levels of innovation (Zellweger and Sieger, 2010). Considering these arguments, hypothesis H3 may be accepted.

Table 5: Entrepreneurship and innovation in ICT

\begin{tabular}{|c|c|c|c|}
\hline Innovation in ICT & Entrepreneurship & $\begin{array}{r}\text { Well-established } \\
\text { businesses }\end{array}$ & Sig. \\
\hline Incorporate ICT into the business & $86.0 \%$ & $89.1 \%$ & $* * *$ \\
\hline Do not incorporate ICT into the business & $14.0 \%$ & $10.9 \%$ & \\
\hline
\end{tabular}

Note: Person's $\chi 2$ test and Yates correction for continuity; $\left(^{*}\right): \mathrm{p}<0.1 ;\left({ }^{* *}\right): \mathrm{p}<0.05 ;\left({ }^{* * *}\right): \mathrm{p}<0.01$;

(NS) Statistically non-significant.

Source: author's design.

As part of entrepreneurship and risk taking, the following Table shows that the majority of the family businesses to a low extent obtain credit lines from financial institutions, mainly due to their risk aversion (Meyer and Zucker, 1989), to the high financial costs and to their fear of losing control of the business (Zellweger and Sieger, 2010). In agreement with these findings, hypothesis $\mathrm{H} 4$ may be accepted.

Table 6: Entrepreneurship and innovation in financial products

\begin{tabular}{lrrr}
\hline Innovation in financial products & Entrepreneurship & $\begin{array}{r}\text { Well-establsihed } \\
\text { businesses }\end{array}$ & Sig. \\
\hline Incorporate electronic payment systems & $30.3 \%$ & $48.5 \%$ & $* * *$ \\
Do not incorpórate electronic payment systems & $69.7 \%$ & $51.5 \%$ & \\
\hline
\end{tabular}

Note: Person's $\chi 2$ test and Yates correction for continuity; $\left({ }^{*}\right): \mathrm{p}<0.1 ;\left({ }^{* *}\right): \mathrm{p}<0.05 ;\left({ }^{* * *}\right): \mathrm{p}<0.01$;

(NS) Statistically non-significant.

Source: author's design.

However, risk taking becomes lower when the family businesses obtain most credits from their suppliers. This can be explained by the fact that suppliers offer greater flexibility of payment without a required contract or high financial costs involved. With these arguments, hypothesis H5 is accepted.

Table 7: Entrepreneurship and risk taking

\begin{tabular}{|c|c|c|c|}
\hline Risk taking & Entrepreneurship & $\begin{array}{r}\text { Well-established } \\
\text { businesses }\end{array}$ & Sig. \\
\hline Yes credit from financial institutions & $19.4 \%$ & $27.1 \%$ & $* * *$ \\
\hline No credit from financial institutions & $80.6 \%$ & $72.9 \%$ & \\
\hline Yes credit from suppliers & $70.8 \%$ & $39.8 \%$ & $* * *$ \\
\hline No credit from suppliers & $29.2 \%$ & $60.2 \%$ & \\
\hline
\end{tabular}

Note: Person's $\chi 2$ test and Yates correction for continuity; $\left(^{*}\right): p<0.1 ;\left(^{* *}\right): p<0.05 ;\left({ }^{* *}\right): p<0.01$;

(NS) Statistically non-significant.

Source: author's design.

Competitive aggressiveness is a characteristic of entrepreneurial family businesses. This situation is mainly influenced by the conservative nature of this type of enterprises to explore new foreign markets or by their resistance to internationalization (Schulze, Lubatkin and Dino, 2002). The next Table shows that the majority of family businesses do not undertake activities that involve participation in international markets during their entrepreneurial stage. Based on Gallo et al.'s. (2008) findings, hypothesis H6 is accepted.

Table 8: Entrepreneurship and competitive aggressiveness

\begin{tabular}{lrrr}
\hline Competitive aggressiveness & Entrepreneurship & $\begin{array}{r}\text { Well-established } \\
\text { enterprises }\end{array}$ & Sig. \\
\hline Engage in export activities & $1.4 \%$ & $6.0 \%$ & $* * *$ \\
Do not engage in export activities & $92.4 \%$ & $92.4 \%$ & \\
\hline
\end{tabular}

Note: Person's $\chi 2$ test and Yates correction for continuity; $\left(^{*}\right): \mathrm{p}<0.1 ;\left({ }^{* *}\right): \mathrm{p}<0.05 ;\left({ }^{* * *}\right): \mathrm{p}<0.01$;

(NS) Statistically non-significant.

Source: author's design.

Regarding the degree of autonomy that family businesses have both internally and externally, it can be observed in the following Table that the majority of family businesses tend to be more autonomous in terms of direction and control during their entrepreneurial stage. This can be accounted for the fact that the majority of them have 
the main owner or partner as the business manager also, which will provide them with greater stability for future generations. Similarly, it can also be observed that the majority of family firms exert a higher degree of autonomy regarding the participation of other external companies or economic groups in the business. These findings are in line with those of Zellweger and Sieger (2010), and therefore, hypothesis H8 can be accepted.

Table 9: Entrepreneurship and autonomy

\begin{tabular}{|c|c|c|c|}
\hline Internal and external autonomy & Entrepreneurship & $\begin{array}{r}\text { Well established } \\
\text { businesses }\end{array}$ & Sig. \\
\hline Business manager is the main owner or partner & $77.6 \%$ & $93.2 \%$ & **** \\
\hline Business manager is not the main owner or partner & $22.4 \%$ & $6.8 \%$ & \\
\hline $\begin{array}{l}\text { Another company or economic group is the owner of } \\
50 \% \text { or more of the business }\end{array}$ & $10.4 \%$ & $12.9 \%$ & $* * *$ \\
\hline $\begin{array}{l}\text { Another company or economic group is not the owner } \\
\text { of } 50 \% \text { or more of the business }\end{array}$ & $89.6 \%$ & $87.1 \%$ & \\
\hline
\end{tabular}

Note: Person's $\chi 2$ test and Yates correction for continuity; $\left({ }^{*}\right): \mathrm{p}<0.1 ;\left({ }^{* *}\right): \mathrm{p}<0.05 ;\left({ }^{* * *}\right): \mathrm{p}<0.01$;

(NS) Statistically non-significant.

Source: author's design.

Additionally and with the purpose of confirming the results obtained through the Chi-squared test, a logistics regression model that includes all the variables established in previous analyses has been utilized. First, an analysis through the automatic step adjustment Wald method was conducted. This method uses the Veracity test REASON to verify the co-variables to be included in or excluded from the established model. The results indicated that the external autonomy variable was eliminated as it has the greatest Odds Ratio (OR) closer to zero, the OR's confidence interval is greater than 1 ; in other words, it does not have any effect on the dependent variable. Once the variables to be included in the model were obtained, an analysis through the introduction method was conducted. The following Table shows the results with their respective probabilities.

Table 10: Binary logistics regression

\begin{tabular}{lrrrrr}
\hline Independent Variables & B & S.E. & Wald & Sig. & Exp (B) \\
\hline Proactivity (business expansion) & -1.364 & .038 & 1312.577 & .000 & .256 \\
Innovation in ICT & .241 & .034 & 49.346 & .000 & 1.273 \\
Innovation in financial products & -.530 & .024 & 471.902 & .000 & .589 \\
Credit from financial institutions & .409 & .028 & 208.206 & .000 & 1.505 \\
Credit from suppliers & -1.168 & .024 & 2367.877 & .000 & .311 \\
Competitive aggressiveness & -2.032 & .031 & 4331.846 & .000 & .131 \\
Internal autonomy & .019 & .000 & 2037.386 & .000 & 1.019 \\
Gender & .349 & .026 & 184.868 & .000 & 1.417 \\
Size & -.105 & .018 & 35.027 & .000 & .900 \\
Sector & .398 & .027 & 213.781 & .000 & 1.488 \\
Constant & .255 & .054 & 22.603 & .000 & .775 \\
\hline
\end{tabular}

Dependent variable Entrepreneurship: 1 , up to 3.5 years; and 0 otherwise.

Notes: B: Logistics coefficients are used to measure changes in the probability ratios, called odds ratio. A positive coefficient increases the forecasted probability, while a negative value lowers it. S.E.: standard error. Wald: Wald test. Sig.: level of significance. $\operatorname{Exp(B):~exponential~coefficient.~The~model's~statistical~significance~has~been~determined~using~the~globally~}$ adjusted Hosmer Lemeshow test, which obtains a statistical contrast that indicates the existence of a statistically significant difference between the observed and the forecasted classifications, as the Chi square value is significant (Chi-square: 2885.35, sig.: 0.000). As a quality adjustment measure, we obtain a global right percentage of $92.2 \%$ if we use a classification function model. Model summary: -2 log likelihood: 62931.98; Cox-Snell R2: 0.088; Nagelkerke R2: 0.191.

Source: Author's design.

\subsection{Discussions}

Based on the results presented above, it can be observed that the Mexican family businesses tend to be less proactive, or more conservative, during their entrepreneurial stage in terms of their expansion or growth to gain a greater competitive advantage; they tend to be more innovative in the use of ICT, but also less innovative in the use of financial products as payment methods; they obtain, to a greater extent, credits from Banks (which is in sharp contrast with the findings in the risk taking crossed tables); they also tend to obtain, to a lesser extent, credits from suppliers, to be less aggressive to compete or explore new foreign markets, and to have greater degrees of internal autonomy for business' direction and control.

With respect to gender, it can be argued that the tendency is for males to hold management positions. This situation can be understood by the division of labor that has traditionally prevailed in the Mexican family business 
culture. According to Ward and Sorenson's (1989), males have historically been in charge of the family business and females have taken up the roles of wifes, housewifes and childcare givers. However, in Mexico, a gradual change has been observed, with females starting to participate more actively in business management activities. Likewise, it was found that most of the entrepreneurial family businesses tend to belong to the tertiary sector of the Mexican economy and are usually smaller in size.

\subsection{Conclusions}

Mexican family businesses' entrepreneurship and particularly their entrepreneurial orientation are topics that have received little attention in the literature. Therefore, the lack of clear definitions and limitations continue to be a challenge for researchers to engage in comparative studies which can help understand different organizational behaviors related to the interaction among the family, the business and the management.

This study aims to explore the Mexican businesses' entrepreneurial orientation during their entrepreneurial stage through their five key dimensions: proactivity, innovation, risk taking, aggressiveness and autonomy. The findings enabled us to confirm the initially proposed hypotheses. This confirms the used variables and their respective results previously obtained by different studies in other contexts such as those of (Meyer and Zucker, 1989; Schulze, Lubatkin and Dino, 2002; Gallo et al., 2008; Zellweger and Sieger, 2010). However, it is acknowledged that Mexican family businesses experience conservative behavior regarding their orientation during their entrepreneurial stage. Once again, marked tendencies are present within them. These include the prevalence of passivity or reactivity and risk aversion. It is important to recall that $90 \%$ of the sample is made up of businesses whose size ranges from micro to small; that is, they have between 6 and 50 employees mainly if we consider the tertiary sector. In this context, it seems relevant and perhaps necessary to include in both the decision making process and the management of family businesses the participation of competent external actors who can counteract such inertia.

We suggest that future studies explore the Mexican family businesses' entrepreneurial orientation taking into consideration the use of constructs developed by international scholars as benchmarks in order to be able to make comparisons. Future studies could also consider the influence of other factors such as the business sector or life cycle's stage of development (Arzubiaga et al., 2012). Such studies could help explain why businesses focus more on some aspects than others, without losing their entrepreneurial orientation.

\section{References}

Aldrich, S. \& Cliff, J. (2003). The pervasive effects of family on entrepreneurship: Toward a family embeddedness perspective. Journal of Business Venturing, 18, 576-596. https://doi.org/10.1016/S0883-9026(03)00011-9

Aragonés, J. (1992). La sucesión en las empresas familiares. Revista Alta Dirección, 162, 37-46.

Arzubiaga, U., Iturralde, T. \& Maseda, A. (2012). La medición de la Orientación Emprendendora en las empresas familiares: una revisión crítica de la literatura. Revista de Empresa Familiar, 2(2), 57-71.

Astrachan, J. (2003). Commentary on the special issue: The emergence of a field. Journal of Business Venturing, 28, 567-572. https://doi.org/10.1016/S0883-9026(03)00010-7

Barnes, L. \& Hershon, S. (1976). Transferring power in the family business. Harvard Business Review, 54, p. 105114.

Baum, J., Locke, E. \& Smith, K. (2001). A multidimensional model of venture growth. Academy of Management Journal, 44, 292-303. https://doi.org/10.2307/3069456

Beckhard, R. \& Dyer, W. (1983). Managing continuity in the family-owned business. Organizational Dynamics, 12(1), p. 5-12. https://doi.org/10.1016/0090-2616(83)90022-0

Benavides, C. A., Guzmán, V. F., \& Quintana, C. Q. (2011). Evolución de la literatura sobre empresa familiar como disciplina científica. Cuadernos de Economía y Dirección de la Empresa, 14(2), 78-90. https://doi.org/10.1016/j.cede.2011.02.004

Bird, B., Welsch, H., Astrachan, J. H. \& Pistrui, D. (2002). Family business research: The evolution of an academic field. Family Business Review, 15(4), 337-350. https://doi.org/10.1111/j.1741-6248.2002.00337.x

Borch, O. Huse, M. \& Senneseth, K. (1999). Resource configuration, competitive strategies and corporate entrepreneurship: An empirical examination of small firms. Entrepreurship Theory and Practice, 24(1), 4970.

Bork, D. (1986). Family Business. Risky Business, New York, NY, USA: Amacom.

Burgelman, R. (1984). Designs for corporate entrepreneurship in established firms. California Management Review, 26(3), 154-166. https://doi.org/10.2307/41165086 
Cabrera, K. \& García, J. (1998). Cambios en la cultura y estructura de las empresas frente a las tecnologías de la información empírica. VIII Congreso Nacional sobre Empresa Familiar de la Asociación Científica de Economía y Dirección de la Empresa (ACEDE), Universidad de las Palmas de la Gran Canaria, Espa-a.

Chandler, A. (1990). Scale and scope: The dynamics of industrial capitalism. Boston, MA: Harvard University Press.

Churchill, N. \& Hatten, K. (1987). Non-market-based transfer of wealth and power: A research framework for family business. American Journal of Small Business, 12, p 53-66.

Covin, J. \& Slevin, D. (1989). Strategic management of small firms in hostile and benign environments. Strategic Management Journal, 10, 75-87. https://doi.org/10.1002/smj.4250100107

Covin, J. \& Slevin, D. (1991). A conceptual model of entrepreneurship as firm behavior. Entrepreneurship Theory and Practice, 16(1), 7-24.

Craig, J. B. \& Moores, K. (2006). A 10-Year Longitudinal Investigation of Strategy, Systems, and Environment on Innovation in Family Firms. Family Business Review, 19 (1), 1-10. https://doi.org/10.1111/j.17416248.2006.00056.x

Cruz, C. \& Nordqvist, M. (2007). Environmental factors and entrepreneurial orientation in family business: A generational perspective. Paper presented at 3rd Workshop on Family Firms Management Research, Jonkoping, Sweden.

Davis, P. (1983). Realizing the potential of the family business. Organizational Dynamics, 12(1), p. 47-56. https://doi.org/10.1016/0090-2616(83)90026-8

Donnelly, R. (1964). The family business. Harvard Business Review, 42 (4), 93-105.

ENAFIN (2010). Encuesta Nacional de Competitividad, Fuentes de Financiamiento y Uso de Servicios Financieros de las Empresas. From http://www.cnbv.gob.mx/CNBV/Estudios-de-la-CNBV/Paginas/Encuesta.aspx

Fama, E. \& Jensen, M. (1983). Separation of ownership and control. Journal of Law and Economics, 26, $301-325$. https://doi.org/10.1086/467037

Gallo, M. \& Sveen, J. (1991). Internationalizing the family business: facilitating and restraining factors. Family Business Review, 2(IV), p.181-190. https://doi.org/10.1111/j.1741-6248.1991.00181.x

Gallo, M. A., Ari-o, A., Má-ez, I. \& Cappuyns, K. (2008). "Internacionalización vía alianzas estratégicas en la empresa familiar", en Transformarse o desaparecer. Estrategias de la empresa familiar para competir en el siglo XXI, Ediciones Deusto, Barcelona, p. 138.

GEM (2014). Global Entrepreneurship Monitor, Global Report 2014. From http://www.babson.edu/Academics/centers/blank-center/globalresearch/gem/Documents/GEM\%202014\%20Global\%20Report.pdf

Guth, W. \& Ginsberg, A. (1990). Guest Editor's Introduction: "Corporate Entrepreneurship". Strategic Management Journal, 11: 5-15.

Handler, W. (1989). Methodological Issues and Considerations in Studying Family Business. Journal of the Family Firm Institute, 2 (3), 257-276.

Hughes, M. \& Morgan, R.E. (2007). Deconstructing the relationship between entrepreneurial orientation and business performance at the embryonic stage of firm growth. Industrial Marketing Management, 36, 651661. https://doi.org/10.1016/j.indmarman.2006.04.003

Ireland, R., Hitt, M. \& Sirmon, D. (2003). A model of strategic entrepreneurship: The construct and its dimensions. Journal of Management, 29(6), 963-989. https://doi.org/10.1016/S0149-2063_03_00086-2

Kanter, R. (1982). The middle manager as innovator. Harvard Business Review, 60(4), 95-106.

Kellermanns, F. \& Eddleston, K. (2006). Corporate venturing in family firms: Does the family matter? Entrepreneurship Theory and Practice, 30(6), 837-854. https://doi.org/10.1111/j.1540-6520.2006.00153.x

Kuratko, D. (2010). Corporate entrepreneurship: An introduction and research review. Handbook of Entrepreneurship Research, 129-163. https://doi.org/10.1007/978-1-4419-1191-9_6

Lumpkin, G. \& Dess, G. (1996). Clarifying the entrepreneurial orientation construct and kinking it to performance. Academy of Management Review, 21-81), 135-172. https://doi.org/10.5465/AMR.1996.9602161568

Lumpkin, G. \& Dess, G. (2001). Linking two dimensions of entrepreneurial orientation to firm performance: The moderating role of environement industry life cycle. Journal of Business Venturing, 16, 429-451. https://doi.org/10.1016/S0883-9026(00)00048-3

Martin, W. \& Lumpkin, G. (2003). From entrepreneurial orientation to family orientation: Generational differences in the management of family business. Paper presented at the Babson College Entrepreneurship Research Conference, Babson College, Wellesley, MA, USA.

Meyer, M. \& Zucker, L. (1989). Permanently failing organizations. Newbury Park, CA: Sage Publications.

Miller, D. (1983). The correlates of entrepreneurship in three types of firms. Management Science, 29, $770-792$. https://doi.org/10.1287/mnsc.29.7.770

Miller, D. (1987); Strategic making and structure: Analysis and implications for performance. Academy of Management Journal, 30: 7-32. https://doi.org/10.2307/255893

Miller, E. \& Rice, A. (1967). System of Organization, Tavistock, London.

Mintzberg, H. (1973). Strategy making in thee modes. California Management Review, 16(2): 44-53. https://doi.org/10.2307/41164491 
Mintzberg, H. \& Waters, J. (1985). Of strategies, deliberate and emergent. Strategic Management Journal, 6: 257 272. https://doi.org/10.1002/smj.4250060306

Moreno, A. \& Casillas, J. (2008). Entrepreneurial orientation and growth os SMEs: A causal model. Entrepreneurship Theory and Practice, 32(3), 507-528. https://doi.org/10.1111/j.1540-6520.2008.00238.x

Morris, M., Kuratko, D. \& Covin, J. (2010). Corporate entrepreneurship \& innovation South-Western Pub.

Naldi, L., Nordqvist, M., Sjöberg, K. \& Wiklund, J. (2007). Entrepreneurial orientation, risk taking, and performance in family firms. Family Business Review, 20(1), 33-47. https://doi.org/10.1111/j.1741-6248.2007.00082.x

Naman, J. \& Slevin, D. (1993). Entrepreneurship and the concept of fit: A model and empirical test. Strategic Management Journal, 14(2), 137-153. https://doi.org/10.1002/smj.4250140205

Nordquvist, M., Habbershon, T. \& Melin, L. (2008). Transgenerational entrepreneurship: Exploring entrepreneurial orientation in family firms. In H. Landström, D. Smallbone, H. https://doi.org/10.4337/9781848443952.00014

Poza, E. (2005). Empresas Familiares. México: Editorial Thomson.

Rauch, A., Wiklund, J., Frese, M. \& Lumpkin, G. (2001). Entrepreneurial orientation and business performance: An assessment of past research and suggestions for the future. Entrepreneurship Theory and Practice.

Rosenblatt, P., de Mik, L., Anderson, R. \& Johnson, P. (1985). The family in business. San Francisco: Jossey-Bass.

Schöllhammer, H. (1982). Internal corporate entrepreneurship. In C. A. Kent, D. L. Sexton, and K. H. Vesper (Eds.), Encyclopedia of entrepreneurship, pp. 209-233. Englewood Cliffs, NJ: Prentice Hall.

Schulze, W., Lubatkin, M. \& Dino, R. (2002). Altruism, agency and the competitiveness of family firms. Managerial and Decision Economics, 23, 247-259. https://doi.org/10.1002/mde.1064

Schumpeter, J. (1934). The theory of economic development. Cambridge, MA: Harvard University Press.

Sharma, P. (2012). 25 years of Family Business Review: reflections on the past and perspectives for the future. Family Business Review, 25, 5-15. https://doi.org/10.1177/0894486512437626

Shrivastava, P. \& Grant, J. (1985). Empirically derived models of strategic decision-making processes. Strategic Management Journal, 6: 97-113. https://doi.org/10.1002/smj.4250060202

Wang, C. (2008). Entrepreneurial orientation, learning orientation, and firm performance. Entrepreneurship Theory and Practice, 32(4), 635-657. https://doi.org/10.1111/j.1540-6520.2008.00246.x

Ward, J. L. \& Sorenson, L. S. (1989). The role of mom. Nation's Business, vol. 11, no 77, pp. 40-41.

Wiklud, J. \& Shepherd, D. (2005). Entrepreneurial orientation and small business performance: A configurational approach. Journal of Business Venturing, 20, 71-91. https://doi.org/10.1016/j.jbusvent.2004.01.001

Wiklud, J. (1999). The sustainability of the entrepreneurial orientation - performance relationship. Entrepreneurship Theory and Practice, 24(1), 37-48.

Webb, J., Ketchen, D. \& Ireland, R. D. (2010). Strategic entrepreneurship within family-controlled firms: Opportunities and challenges. Journal of Family Business Strategy, 1(2), 67-77. https://doi.org/10.1016/j.jfbs.2010.04.002

Wortman, M.S. Jr. (1994). Theoretical foundations for family-owned business: a conceptual and research -based paradigm, Family Business Review, Journal of the Family Firm Institute, USA, 7 (1), 3-27.

Yu, A., Lumpkin, G. T., Sorenson, R. L. \& Brigham, K. H. (2012). The landscape of family business outcomes a summary and numerical taxonomy of dependent variables. Family Business Review, 25(1), 33-57. https://doi.org/10.1177/0894486511430329

Zahra, S. (1991). Predictors and financial outcomes of corporate entrepreneurship: An exploratory study. Journal of Business Venturing, 6, 259-285. https://doi.org/10.1016/0883-9026(91)90019-A

Zahra, S. \& Covin, J. (1993). Business strategy, technology policy and firm performance. Strategic Management Journal, 14: 451-478. https://doi.org/10.1002/smj.4250140605

Zahra, S. \& Garvin, D. (2000). International corporate entrepreneurship and firm performance: The moderating effects of international environment hostility. Entrepreneurship Theory and Practice, 15(4), 469-492. https://doi.org/10.1016/s0883-9026(99)00036-1

Zellweger, T., Nason, R. S. \& Nordqvist, M. (2012). From longevity of firms to transgenerational entrepreneurship of families introducing family entrepreneurial orientation. Family Business Review, 25(2), 136-155. https://doi.org/10.1177/0894486511423531

Zellweger, T. \& Sieger, P. (2010). Entrepreneurial orientation in long-lived family firms, Small Business Economics, D0I10.1007/s11187-010-9267-6. https://doi.org/10.1007/s11187-010-9267-6 